\title{
A Single Dose of Indomethacin Does Not Prolong Premotor Reaction Time in Young, Healthy Adults: A Randomized, Placebo-Controlled, Double-Blind, Cross-Over Study
}

\author{
Tek Doz Indometazin Sağlıklı Genç Erişkinlerde Premotor Reaksiyon Zamanını Uzatmıyor: \\ Randomize, Placebo Kontrollü, Çift Kör, Çapraz Geçişli Çalışma
}

Özden ÖZYEMIŞCİ TAŞKIRAN, Aslı GENCAY CAN, Zafer GÜNENDİ, Mehmet BEYAZOVA

Department of Physical Medicine and Rehabilitation, Medical Faculty of Gazi University, Ankara, Turkey

\begin{abstract}
Objectives: In this study, we aimed to investigate the hypothesis that a single dose of indomethacin may affect information processing speed in healthy subjects.

Patients and methods: In this cross-sectional, randomized, placebo controlled, double-blind, cross-over study, 30 healthy adults (8 males, 22 females; mean age $32.4 \pm 5.3$ years; range 24 to 42 years) received a single dose of $25 \mathrm{mg}$ indomethacin (Endol, oral capsule, DEVA Pharmaceutics, Kartepe, Turkey) and placebo. Premotor reaction and response times were measured electromyographically before and after the administration of preparations by a blinded researcher in the Electrophysiology Laboratory at Gazi University, Faculty of Medicine, Department of Physical Medicine and Rehabilitation, Ankara.
\end{abstract}

Results: Premotor reaction time measurements before and after a single dose of indomethacin were 169.1 \pm 36.3 and $160.2 \pm 29.5 \mathrm{msec}$, respectively $(p=0.113)$. Premotor reaction time measurements before and after a single dose of placebo were $158.7 \pm 35.5$ and $161.5 \pm 36.3$ msec, respectively $(p=0.516)$. There was also no statistically significant difference between premotor reaction time measurements of the indomethacin and placebo groups.

Conclusion: A single dose of indomethacin did not change premotor reaction time and response time in healthy adults. This may suggest that indomethacin has no effect on the information processing speed in healthy adults.

Key words: Cognitive function; electromyography; indomethacin; premotor time; reaction time.
Amaç: $\mathrm{Bu}$ çalışmada sağlıklı bireylerde tek doz indometazinin bilgi işlem hızını etkileyebileceği hipotezi araştırıldı.

Hastalar ve yöntemler: Kesitsel, randomize, plasebo kontrollü, çift kör, çapraz geçişli bu çalışmada, 30 sağlıklı erişkin bireye (8 erkek, 22 kadın; ort. yaş 32.4 45.3 yıl; dağılım 24-42 yıl) tek doz 25 mg'lık indometazin (Endol, oral kapsül, DEVA İlaç, Kartepe, Türkiye) ve plasebo uygulandı. İlaç uygulamaları öncesi ve sonrası premotor reaksiyon zamanı ve tepki zamanı çalışmaya kör bir araştırmacı tarafından Ankara Gazi Üniversitesi Tıp Fakültesi Fiziksel Tıp ve Rehabilitasyon Anabilim Dalı Elektrofizyoloji Laboratuvarı'nda elektromiyografik olarak ölçüldü.

Bulgular: Tek doz indometasin öncesi ve sonrası premotor reaksiyon zamanları sırasıyla $169.1 \pm 36.3$ ve $160.2 \pm 29.5$ msn ( $p=0.113)$ olarak ölçüldü. Tek doz plasebo öncesi ve sonrası premotor reaksiyon zamanları sırasıyla $158.7 \pm 35.5$ ve $161.5 \pm 36.3 \mathrm{msn}(p=0.516)$ olarak ölçüldü. Indometazin ve plasebo grupları arasında premotor reaksiyon zaman ölçümleri açısından istatistiksel anlamlı fark saptanmadı.

Sonuç: Tek doz indometazin sağlıklı erişkinlerde premotor reaksiyon zamanı ve tepki zamanı ölçümlerini değiştirmedi. Indometazinin sağlıklı erişkinlerde bilgi işlem hızını etkilemediği düşünülebilir.

Anahtar sözcükler: Bilişsel fonksiyon; elektromiyografi; indometazin; premotor zamanı; reaksiyon zamanı.

\footnotetext{
Received: August 23, 2011 Accepted: January 19, 2012

Correspondence: Özden Özyemişci Taşkıran, M.D. Gazi Üniversitesi Tıp Fakültesi, Fiziksel Tıp ve Rehabiltasyon Anabilim Dalı, 06500 Beşevler, Ankara, Turkey. Tel: +90 312 - 2026858 e-mail: ozdenozyemisci@yahoo.com (O2012 Turkish League Against Rheumatism. All rights reserved.
} 
Indomethacin is a potent nonselective cyclooxygenase (COX) inhibitor used for numerous indications in rheumatology and rehabilitation clinics. It has more common adverse effects than other nonsteroidal antiinflammatory drugs (NSAIDs). When it crosses the blood-brain barrier, the central nervous system is especially affected with symptoms such as headaches, dizziness, drowsiness, confusion, lightheadedness, insomnia, syncope, convulsions, and even comas having been reported. ${ }^{[1]}$ On the other hand, distribution into the central nervous system may be an advantage with some conditions as it may prevent the development of intraventricular hemorrhage in neonates, ${ }^{[1]}$ enhance neurogenesis after cerebral ischemia, ${ }^{[2]}$ or be used as chemoprevention in glioma cell lines. ${ }^{[3]}$ The mechanisms underlying these effects are not precisely known.

Epidemiological studies have brought about the possible protective role of NSAIDs against Alzheimer's disease (AD) ${ }^{[4]}$ Although its use in AD treatment has not been proven by evidence-based results, ${ }^{[5]}$ improvement in cognitive parameters in the Alzheimer's Disease Assessment Scale (ADAS) have been observed with indomethacin. ${ }^{[6]}$

A variety of neuropsychological tests are used to measure the multidimensional aspects of cognition. ${ }^{[7]}$ The reaction time measurement is a component of some of these tests, and the speed of information processing is assessed by the reaction time measurement. Simple and choice reaction times can be evaluated by more widely used computer-based programs and also by electromyography. In simple reaction time, the perception of stimulus and programming of the response are executed without a response selection. ${ }^{[8]}$

The reaction time is the time interval between the presentation of a stimulus and the initiation of a response, and it is fractionated into the premotor and motor times. The premotor time is the time interval between the onset of the stimulus and the onset of the electromyographic activity of the relevant muscle, and the motor time is the time interval between the onset of the electromyographic activity and the onset of the actual muscle response. The amount of time taken for the completion of the task after it has been initiated is called the movement time. The sum of the reaction and movement times constitutes the response time. ${ }^{[9]}$

In the present study, we used a simple reaction time task to test the hypothesis that a single dose of indomethacin would affect the information processing speed in healthy subjects.

\section{PATIENTS AND METHODS}

The study was performed using a randomized, placebo-controlled, double-blind, cross-over design. The study protocol received the approval of the local ethics committee, and the subjects gave their informed written consent in line with the Declaration of Helsinki. Thirty healthy adult subjects (eight males, 22 females; mean age $32.4 \pm 5.3$ years; range 24 to 42 years) were enrolled in this study. The mean education level of the participants was $13.1 \pm 4.5$ years. Subjects with diabetes mellitus, alcoholism, neurological, psychiatric, cardiorespiratory, or renal diseases were not included in the study. Also, anyone taking sedatives, neuroleptic, or antiepileptic drugs was excluded.

All subjects abstained from all medications, including vitamin supplements, NSAIDs, antihistamines, cold medications and performanceenhancing substances during the study. Alcohol and caffeine consumption were prohibited during the 24 hours preceding the tests. All subjects were nonsmokers or smoked fewer than 10 cigarettes a day.

The reaction time task was performed in a quiet room to minimize the diversion of attention. The task performed in the study was one of simple reaction time. The subjects sat in a chair with their backs supported and forearms in their lap and were not allowed to talk during the assessment. The participants were instructed to press a button, which was located on a vertical platform placed at arm's length, in response to a painless electrical stimulus applied to the dorsum of the nondominant hand with a surface stimulation electrode at a mean intensity of $4 \mathrm{~mA}$. The active recording surface electrode was placed over the anterior fibers of the deltoid muscle $3-4 \mathrm{~cm}$ beneath the anterior margin of the acromion. The reference surface electrode was placed $3 \mathrm{~cm}$ proximal to the active electrode. Disk electrodes of $7 \mathrm{~mm}$ in diameter (NE-132B with two-pin plug, DIN type) were fixed by elastic fixation tape. To reduce skin resistance, electrically conductive gel [water-soluble electrocardiogram (ECG) and electroencephalographic (EEG) gel] was applied to the skin beneath the disk electrodes. The ground electrode was attached on the nondominant forearm.

Participants were made ready in the Laboratory of Electrophysiology in Gazi University, Faculty of Medicine, Department of Physical Medicine and Rehabilitation between 9.00 and 9.30 AM. They had been instructed to have their breakfast one hour before the trial. The baseline assessment of reaction 
time measurements was performed at $9.30 \mathrm{AM}$. Immediately after the completion of the baseline tests, participants consumed a single dose of either $25 \mathrm{mg}$ indomethacin or a placebo in the presence of the researcher. Since peak plasma levels of indomethacin are reached approximately two hours after ingestion, ${ }^{[1]}$ the measurements were repeated two hours later. The placebo and $25 \mathrm{mg}$ indomethacin were prepackaged in the form of capsules in the laboratory of Gazi University Faculty of Pharmacy, Division of Pharmaceutics Technology and were identical in appearance. Subjects were randomly assigned whether to take the placebo or indomethacin first. Two days after the first trial, the test protocol was repeated with the administration of the remaining preparation. The plasma half life of indomethacin has been reported to range between 2.6 and 11.2 hours (1), so an interval of 2 days was given between the administration of indomethacin and placebo.

Simple reaction time measurements were performed on a Nihon Kohden Neuropack $\Sigma$ 8-channel electromyography device (Nihon Kohden Corporation, Tokyo, Japan). High and low pass filters were set at $3 \mathrm{kHz}$ and $2 \mathrm{~Hz}$, respectively. The analysis time was $0.2 \mathrm{sec} /$ division and the, sensitivity was $1 \mathrm{mV} /$ division. The participants were given a sufficient number of trials to become familiar with the procedure. For each practice trial, a verbal "ready" signal prompted the subject to prepare for the stimulus presentation which occurred after a randomly determined period of two to five seconds. The experimental trials were performed following the practice. During the test procedure, no feedback or warning signal was given. Test trials were repeated 10 times. $^{[10]}$ Any score of less than $60 \mathrm{msec}$ or over $350 \mathrm{msec}$ in premotor reaction time measurements was considered erroneous and was replaced with a substitute trial. Data was stored and assessed by a blinded researcher.

A power analysis indicated that 24 subjects were needed to detect a mean difference of $14.72 \mathrm{msec}$ (standard deviation 24.83) in premotor time, with $80 \%$ power and a $5 \%$ significance level, ${ }^{[1]]}$ but having 30 participants in the study compensated for possible participant drop out.

\section{Statistical analysis}

The data was analyzed using Statistical Package for Social Sciences (SPSS Inc., Chicago, Illinois, USA) for Windows version 10.0 software. The results were presented as means (standard deviations). Data was tested for the normality of the distribution using the
Kolmogorov Smirnov test and parametric statistical analysis was performed. For each set of 10 reaction time measurements, mean values were put into the analysis. In order to define the difference in the reaction time measurements after dispensing the placebo and indomethacin, the mean values were analyzed via a paired samples t-test for each situation. The mean difference values were then calculated by subtracting the mean values of the baseline measurements from the second measurements. Univariate analysis of variance (ANOVA), including sequence, period, treatment as fixed variables, and subject within sequence as random factors, was used to define the difference between the mean difference values of the indomethacin and placebo administrations. Carry-over effects were also assessed. A statistically significant level was set at $\mathrm{p}<0.05$.

\section{RESULTS}

The premotor reaction time measurements for the indomethacin and placebo administration for each subject are shown in Figure 1a and $1 \mathrm{~b}$, respectively. The response time measurements are also presented in Figure 2.

The mean values of the premotor and response time measurements before and after a single dose of indomethacin and placebo are presented in Table 1. The mean baseline values of the premotor and response times were similar with both $(\mathrm{p}=0.058$; and $\mathrm{p}=0.224$, respectively). There was no statistically significant difference after taking the placebo or indomethacin compared with the baseline values.

The mean difference values of the premotor time measurements did not differ between the indomethacin $(-8.87 \mathrm{msec})$ and placebo $(2.77 \mathrm{msec})$ groups $(p=0.290)$. The mean difference values of the response time measurements for the indomethacin and placebo groups were 14.23 and $15.30 \mathrm{msec}$, respectively $(p=0.938)$. The two sequences were not significantly different from each other ( $p$ value for premotor time: 0.609; $p$ value for response time: 0.795 ). Also, there was no significant difference between periods ( $p$ value for premotor time: 0.078; $p$ value for response time: 0.947 ).

The $p$ value of 0.166 for the mean premotor time measurements and 0.858 for the response time measurements between sequences showed that the possible carry-over effect is not significantly different.

\section{DISCUSSION}

A single dose of $25 \mathrm{mg}$ indomethacin did not prolong either response time measurements or premotor 
(a)

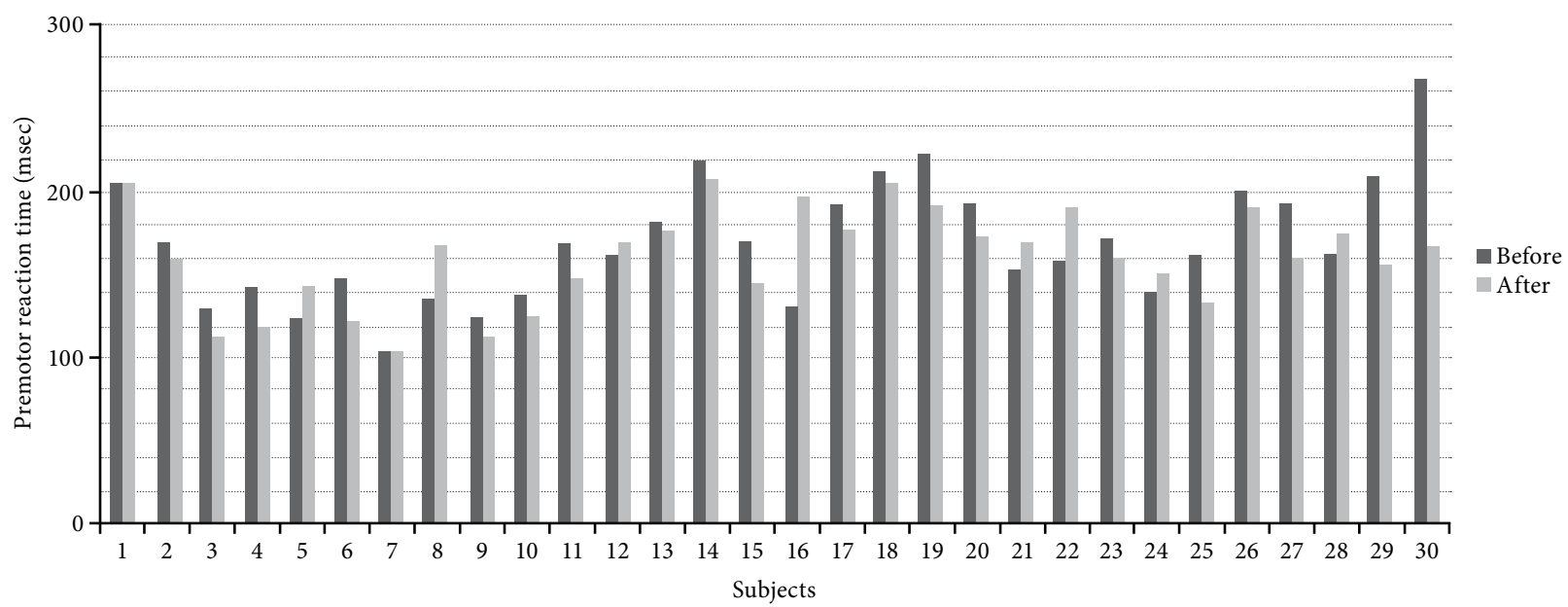

(b)

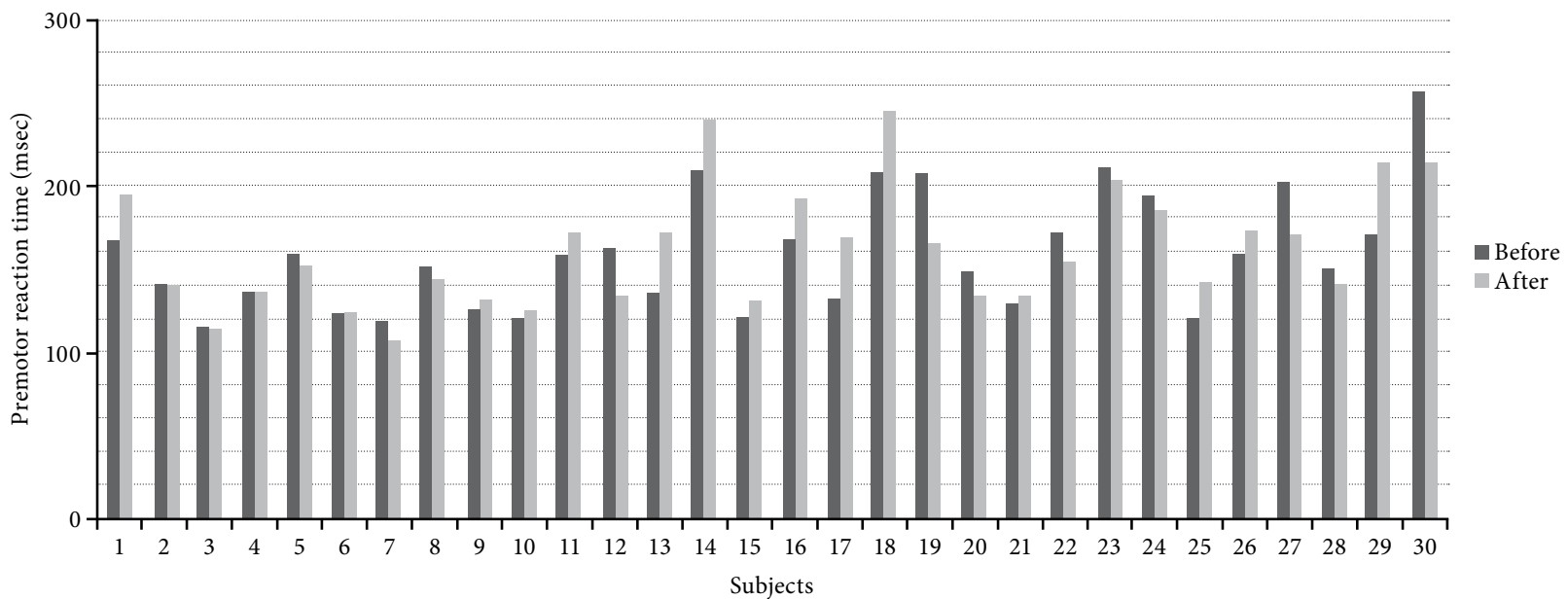

Figure 1. Premotor time measurements before and after (a) indomethacin and (b) placebo administration for each subject.

time measurements in a simple reaction time task in healthy adults. It can be concluded from this study that indomethacin does not lower the information processing speed in healthy adults. Moreover, the premotor time values in the study had a tendency to decline after the indomethacin administration, but the difference did not reach statistical significance $(p=0.290)$. However a similar decline tendency was not observed in the response time measurements.

Indomethacin is thought to improve cognition in $\mathrm{AD},{ }^{[4,6]}$ and in prematurely born children. ${ }^{[12]}$ The mechanisms responsible for its effects on the cognitive system are not the subject of the present study. However, results obtained from previous studies might assist in interpreting our findings. As a potent nonselective COX inhibitor, it has been hypothesized that indomethacin causes vasoconstriction and a decline in cerebral blood flow. ${ }^{[13,14]}$ Besides its effects on cerebral blood flow and vascular reactivity, indomethacin suppresses the mediators of central nervous system (CNS) inflammation. ${ }^{[12]}$ However, this neuroprotective action ${ }^{[15]}$ has not been verified in all studies. ${ }^{[16]}$ While the COX system is accused of playing an important role in neuroinflammation and neuronal damage leading to cognitive impairments, ${ }^{[17,18]}$ it may also be helpful with regard to its anti-inflammatory activity. ${ }^{[15,18]}$ While controversy on the relationship between neuroprotective effects and different COX subtypes continues, similar debate about the effects of the COX system on cognitive impairment also exists. ${ }^{[16,19]}$ The neuroprotective effects may also be explained by mechanisms other than anti-inflammatory actions, for example mitochondrial depolarization, ${ }^{[20]}$ inhibition of caspase activity along with the reversal of depletion in glutathione ${ }^{[15]}$ or antithrombotic effects. ${ }^{[21]}$

Because of the absence of neuroinflammation in our study population, cognitive improvement after the administration of indomethacin cannot be addressed. 
(a)

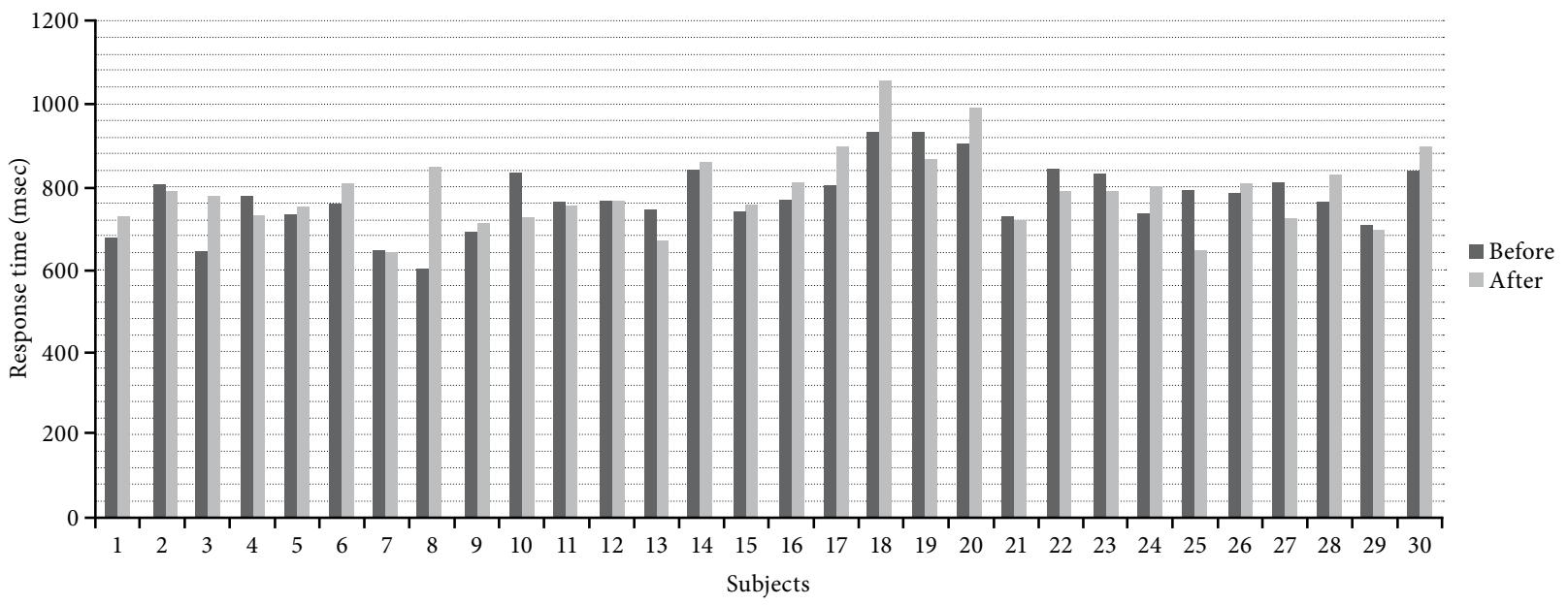

(b)

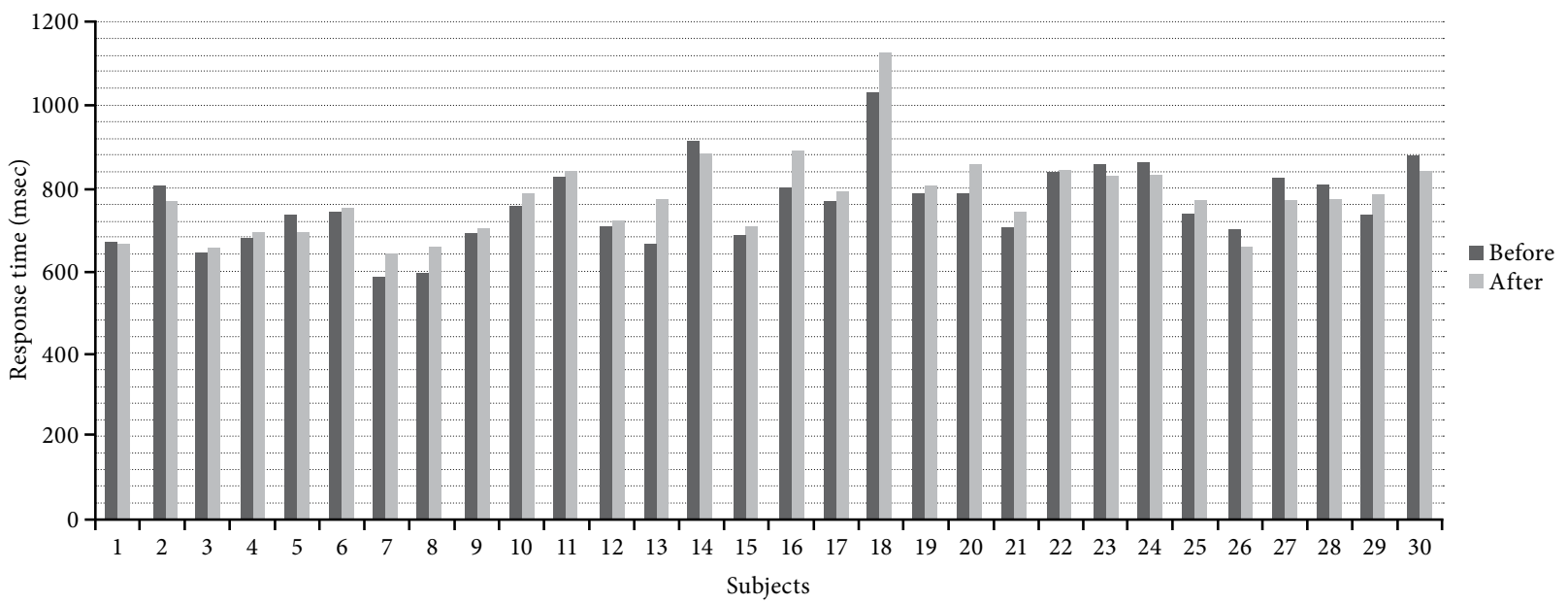

Figure 2. Response time measurements before and after (a) indomethacin and (b) placebo administration for each subject.

However, it can be deduced that acute cognitive decline is not a predicted adverse effect in conjunction with the other aforementioned side effects in healthy individuals. In order to elucidate the pathophysiology of the central nervous system with regard to the side effects of indomethacin, Seideman and von $\operatorname{Arbin}^{[14]}$ investigated cerebral blood flow in healthy subjects and showed that there were no differences in cerebral blood flow reductions in subjects either with or without these side effects. However, cognitive function was not affected in our study population.

Attention allocation is an important predictor of reaction time. Patients suffering from pain might have a longer reaction time due to limited allocated attention in a reaction time task. Indomethacin may promote a higher information processing speed in patients with rheumatologic diseases by relieving musculoskeletal pain. However Pullar et

\begin{tabular}{|c|c|c|c|c|c|c|}
\hline & \multicolumn{3}{|c|}{ Indomethacin $(\mathrm{n}=30)$} & \multicolumn{3}{|c|}{ Placebo $(n=30)$} \\
\hline & Before & After & $p$ & Before & After & $p$ \\
\hline & Mean \pm SD & Mean \pm SD & & Mean \pm SD & Mean \pm SD & \\
\hline Premotor reaction time (msec) & $169.1 \pm 36.3$ & $160.2 \pm 29.5$ & 0.113 & $158.7 \pm 35.5$ & $161.5 \pm 36.3$ & 0.516 \\
\hline Response time (msec) & $772.0 \pm 80.1$ & $786.2 \pm 92.9$ & 0.338 & $757.7 \pm 96.2$ & $773.0 \pm 96.8$ & 0.067 \\
\hline
\end{tabular}


al. ${ }^{[22]}$ observed that indomethacin did not improve the choice reaction time in patients with rheumatic diseases. Moreover, they found psychomotor disturbance after a single dose of indomethacin using critical flicker fusion threshold techniques, but their study population was too small to make the conclusion that indomethacin produced psychomotor disturbance.

Bruce-Jones et al. ${ }^{[23]}$ demonstrated the beneficial effect on choice reaction time latency both after a single dose and after a seven-day administration of indomethacin in healthy elderly subjects. Their findings were similar to our study in that they did not find a significant difference in the movement time. We suggest that the possibility of subclinical neuroinflammation in healthy elderly subjects might explain the improvement of reaction time after the participants were administered indomethacin. The reason why this same improvement was not observed in our study may be because of the younger age of our participants.

In this study, the effect of both a single dose and a low dose of indomethacine were investigated; therefore, a recommendation about the effects of longer administration of higher doses on reaction time cannot be made. This was a limitation of our study.

In most previous studies, the reaction time measurements were administered using microcomputers. They actually measured response time that included movement time. Our study is unique since we measured the premotor reaction time via electromyography, which actually represents cognitive functions more precisely. On the other hand, electromyographic measurement is time consuming and requires expensive equipment along with good cooperation from the subject.

In future studies, the effects of indomethacin on cognition in elderly subjects and in patients with rheumatologic diseases should be investigated using electromyographic reaction time measurements. To test the hypothesis that indomethacin enhances cognitive function by decreasing neuroinflammation, reaction time measurements in elderly patients with cognitive deficits should also be evaluated via electromyography to interpret information about processing speed without interference of peripheral mechanisms.

In conclusion, a single dose of indomethacin had no effect on the premotor reaction time or response time in healthy adults, and the information processing speed did not decline.

\section{Declaration of conflicting interests}

The authors declared no conflicts of interest with respect to the authorship and/or publication of this article.

\section{Funding}

The authors received no financial support for the research and/or authorship of this article.

\section{REFERENCES}

1. Reynolds JEF, Parfitt K, Parsons AV, Sweetman SC, editors. In: Martindale the extra pharmacopoeia. 31st ed. London: Royal Pharmaceutical Society; 1996. p. 51-4.

2. Hoehn BD, Palmer TD, Steinberg GK. Neurogenesis in rats after focal cerebral ischemia is enhanced by indomethacin. Stroke 2005;36:2718-24.

3. Bernardi A, Bavaresco L, Wink MR, Jacques-Silva MC, Delgado-Cañedo A, Lenz G, et al. Indomethacin stimulates activity and expression of ecto-5'nucleotidase/CD73 in glioma cell lines. Eur J Pharmacol 2007;569:8-15.

4. McGeer PL, Schulzer M, McGeer EG. Arthritis and antiinflammatory agents as possible protective factors for Alzheimer's disease: a review of 17 epidemiologic studies. Neurology 1996;47:425-32.

5. Tabet N, Feldman H. Indomethacin for the treatment of Alzheimer's disease patients. Cochrane Database Syst Rev 2002;CD003673.

6. Rogers J, Kirby LC, Hempelman SR, Berry DL, McGeer PL, Kaszniak AW, et al. Clinical trial of indomethacin in Alzheimer's disease. Neurology 1993;43:1609-11.

7. Michon A. The concept of mild cognitive impairment: relevance and limits in clinical practice. Front Neurol Neurosci 2009;24:12-9.

8. Kutukcu Y, Marks WJ Jr, Goodin DS, Aminoff MJ. Simple and choice reaction time in Parkinson's disease. Brain Res 1999;815:367-72.

9. Dickstein R, Hocherman S, Amdor G, Pillar T. Reaction and movement times in patients with hemiparesis for unilateral and bilateral elbow flexion. Phys Ther 1993;73:374-80.

10. Günendi Z, Taskiran OO, Beyazova M. What is the optimal repetition number in electromyographic reaction time studies? Clin Biomech (Bristol, Avon) 2005;20:754-8.

11. Ozyemisci-Taskiran O, Gunendi Z, Bolukbasi N, Beyazova $M$. The effect of a single session submaximal aerobic exercise on premotor fraction of reaction time: an electromyographic study. Clin Biomech (Bristol, Avon) 2008;23:231-5.

12. Ment LR, Peterson BS, Meltzer JA, Vohr B, Allan $\mathrm{W}$, Katz $\mathrm{KH}$, et al. A functional magnetic resonance imaging study of the long-term influences of early indomethacin exposure on language processing in the brains of prematurely born children. Pediatrics 2006; 118:961-70. 
13. Upton RN, Rasmussen M, Grant C, Martinez AM, Cold GE, Ludbrook GL. Pharmacokinetics and pharmacodynamics of indomethacin: effects on cerebral blood flow in anaesthetized sheep. Clin Exp Pharmacol Physiol 2008;35:317-23.

14. Seideman P, von Arbin M. Cerebral blood flow and indomethacin drug levels in subjects with and without central nervous side effects. Br J Clin Pharmacol 1991;31:429-32.

15. Taskin E, Ozcan K, Canacankatan N, Satar M, Yapicioglu HY, Erdogan S. The effects of indomethacin on caspases, glutathione level and lipid peroxidation in the newborn rats with hypoxic-ischemic cerebral injury. Brain Res 2009;1289:118-23.

16. Institoris A, Farkas E, Berczi S, Sule Z, Bari F. Effects of cyclooxygenase (COX) inhibition on memory impairment and hippocampal damage in the early period of cerebral hypoperfusion in rats. Eur J Pharmacol 2007;574:29-38.

17. Choi SH, Bosetti F. Cyclooxygenase-1 null mice show reduced neuroinflammation in response to beta-amyloid. Aging (Albany NY) 2009;1:234-44.

18. Leroux P, Hennebert C, Catteau J, Legros H, Hennebert O, Laudenbach $\mathrm{V}$, et al. Neuroprotective effects vary across nonsteroidal antiinflammatory drugs in a mouse model of developing excitotoxic brain injury. Neuroscience 2010;167:716-23.

19. Harding DR, Humphries SE, Whitelaw A, Marlow $\mathrm{N}$, Montgomery HE. Cognitive outcome and cyclooxygenase-2 gene $(-765 \mathrm{G} / \mathrm{C})$ variation in the preterm infant. Arch Dis Child Fetal Neonatal Ed 2007; 92:F108-12.

20. Sanz-Blasco S, Valero RA, Rodríguez-Crespo I, Villalobos C, Núñez L. Mitochondrial Ca2+ overload underlies Abeta oligomers neurotoxicity providing an unexpected mechanism of neuroprotection by NSAIDs. PLoS One 2008;3:e2718.

21. Buccellati C, Folco GC, Sala A, Scelsi R, Masoero E, Poggi $\mathrm{P}$, et al. Inhibition of prostanoid synthesis protects against neuronal damage induced by focal ischemia in rat brain. Neurosci Lett 1998;257:123-6.

22. Pullar T, Myall O, Haigh JR, Lowe JR, Dixon JS, Bird HA. The effect of indomethacin on the psychomotor function of patients with rheumatic diseases. Br J Rheumatol 1988;27:227-9.

23. Bruce-Jones PN, Crome P, Kalra L. Indomethacin and cognitive function in healthy elderly volunteers. Br J Clin Pharmacol 1994;38:45-51. 